Avalaible online: https://ejournal.iai-tribakti.ac.id/index.php/pgmi

Article doi: https://doi.org/10.33367/jiee.v3i2.1917

Submission: 2021-08-19 Review: 2021-09-04 Revision: 2021-09-28 Accepted: 2021-09-28

\title{
Efektifitas Metode Scramble Dalam Pembelajaran Pendidikan Agama Islam di SDN Balonggabus Sidoarjo
}

\section{The Effectiveness of the Scramble Method in Learning Islamic Religious Education at Balonggabus Elementary School Sidoarjo}

\author{
Femiliana Hakim ${ }^{1}$ \\ ${ }^{1}$ SDN Balonggabus Candi Sidoarjo \\ 1 femihakim@gmail.com
}

\begin{abstract}
Islamic religious education learning (PAI) at elementary school has been dominated teacher and is not conducted maximally. This causes students' attention less focused in the teaching and learning process. To overcme this problem, it needs an alternative learning method. This article is descriptive analytic using a qualitative approach. The data is collected used literature study. The research results indicate three things. The first is, the scramble method is a relatively new learning technique, it also makes students are actively involved in the teaching and learning process. The second is, PAI learning is still dominated by the teacher which causes students to be less active and resulted learning outcomes too low. The third is, the scramble method is very important to be applied in PAI learning for elementary schools. This is done to improve student learning outcomes and change the monotonous learning methods.
\end{abstract}

Keyword: Scramble, PAI, Elementary School.

\begin{abstract}
Abstrak
Pembelajaran pendidikan agama Islam (PAI) pada jenjang sekolah dasar menunjukkan masih didominasi belum berlangsung secara maksimal. Hal ini menyebabkan perhatian siswa kurang fokus saat belajar di sekolah. Diperlukan metode pembelajaran alternatif untuk mengakhiri permasalahan ini. Artikel ini bersifat deskriptif-analitik dengan menggunakan pendekatan kualitatif. Pengumpulan datanya menggunakan studi kepustakaan. Hasil pembahasan tulisan ini menunjukkan kepada tiga hal. Pertama menunjukkan bahwa metode scramble adalah teknik pembelajaran yang tergolong baru dan mampu menjadikan siswa aktif dalam proses pembelajaran. Kedua adalah kondisi pembelajaran PAI selama ini masih didominasi oleh metode ceramah yang menyebabkan siswa kurang aktif sehingga hasil belajar siswa masih tergolong rendah. Ketiga adalah metode scramble semakin penting (urgent) untuk diterapkan dalam pembelajaran PAI pada sekolah dasar. Hal ini didorong keinginan untuk menaikkan hasil belajar siswa dan mengakhiri metode pembelajaran yang selama ini masih monoton
\end{abstract}

Kata Kunci: Scramble, PAI, Sekolah Dasar. 


\section{Pendahuluan}

Dalam penyelenggaraan pendidikan, inovasi dan kretifitas guru memilih metode pembelajaran masih menjadi permasalahan tersendiri. Fenomena ini menjadikan, penelitian bidang metode pembelajaran tidak pernah habis dan akan terus berkembang. Ketika menggunakan perspektif Syaiful Bahri, metode pembelajaran akan terus berkembang sesuai dengan perkembangan dinamika pendidikan itu sendiri. Maka tidak mungkin, guru yang hanya menguasai satu metode pembelajaran akan berhasil menlakukan kegaitan belajar mengajar dengan baik. ${ }^{1}$

Penelitian ini berfokus pada implementasi metode scramble yang mulai banyak digunakn oleh guru jenjang sekolah dasar. ${ }^{2}$ Secara umum, metode scramble adalah metode pembelajaran yang membutuhkan media dengan pertanyaan dan jawaban dalam kertas menarik. Penerapannya memanfaatkan kecapakan kerjasama antar siswa dalam kelompok untuk mencocokkan pertanyaan dan jawaban yang ditulis dalam kertas tersebut. ${ }^{3}$ Selama ini, hasil penerapan metode ini sangat efisien, mampu meningkatkan hasil pembelajaran dengan sangat signifikan. ${ }^{4}$

Gian Handini menegaskan bahwa scramble mampu meningkatkan hasil belajar dan keaktifan siswa dalam pembelajaran mata pelajaran IPS pada jenjang sekolah dasar. ${ }^{5}$ Andika Sofyan juga menegaskan hal yang sama, terutama dalam mata pelajaran Fikih pada madrasah tsanawiyah di lingkup Kementerian Agama. ${ }^{6}$ Pada jenjang SMA, penelitian Nurlina dalam pembelajaran mata pelajaran Fisika juga menyimpulkan hal yang sama, terutama dalam

${ }^{4}$ Isna Fitriana, "Penerapan Model Pembelajaran Scramble Untuk Meningkatkan Hasil Belajar Siswa Pada Materi Tata Nama Senyawa Di SMAN 1 Bireuen," Skripsi (Lampung: IAIN Randen Intan Lampung, 2016).

${ }^{5}$ Gian Handini, "Penerapan Model Pembelajaran Scramble Untuk Meningkatkan Hasil Belajar IPS Siswa Kelas V SDN 21 Palembang," Skripsi (Palembang: Universitas Sriwijaya, 2016).

${ }^{6}$ Andika Sofyan, "Penerapan Metode Scramble Untuk Meningkatkan Hasil Belajar Fiqih Siswa Kelas VIII E MTS Negeri 1 Lampung Timur Tahun Pelajaran 2018/2019, Skripsi (Lampung Timur: IAIN Metro, 2019).

el Bidayah: Journal of Islamic Elementary Education Volume 3, Nomor 2, September 2021 
aspek motivasi belajar siswa. ${ }^{7}$ Sedangkan hasil penelitian Isna Fitriana menunjukkan bahwa scramble juga sama-sama mampu meningkakan hasil belajar siswa di lokasi penelitian.

Meski demikian, penelitian terdahulu belum merujuk pada kreteria penerapan metode scramble. Pasalnya, secara indikator penyebutan guru professional adalah guru yang mampu menggunakan metode dengan sangat baik. Kreterianya, dia menguasai yang didukung pengakuan secara administrasi, misalnya sertifikat pengakuan telah melakukan bimtek tengan metode pembelajaran. Karena guru dituntut untuk memenuhi dan mencapai tujuan pembelajaran dan pendidikan secara nasional. ${ }^{8}$

Secara umum, penjelasan istilah guru tidak ada yang berbeda. Guru merupakan pekerjaan seseorang dalam melakukan trasformasi keilmuan dan nilai-nilai sesuai tujuan pendidikan nasional. ${ }^{9}$ Artinya, guru-guru dalam bekerja harus mencetak siswa sesuai dengan tujuan pendidikan nasional. Hal

${ }^{7}$ Nurlina, "Penerapan Metode Scramble Untuk Meningkatkan Motivasi Belajar Fisika Siswa Kelas X SMA Muhammadiyah Unismuh Makassar," Skripsi (Makassar: Universitas Muhammadiyah, 2018).

8Sardiman, Interaksi dan Motivasi Belajar Mengajar (Jakarta: PT Grafindo Persada, 2012), 125. ini juga berlaku pada guru-guru yang bekerja di sekolah dasar (SD). Hadari Nawawi guru-guru sekolah dasar bertanggung jawab dalam membentuk anak-anak mencapai kedewasaan yang sesuai dengan tjuan pendidikan nasional.

Jika dilihat lebih dalam, pandangan Hadari Nawawi menjelasakan, bahwa mata pelajaran Pendidikan Agama Islam selaras dengan tujuan pendidikan nasional yaitu, mewujudkan manusia yang berakhlak mulia baik secara lahir maupun batin dan mampu mengabdikan segala amal perbuatannya untuk mencari keridhoan Allah Swt. ${ }^{10}$ Dalam kurikulum nasional, PAI menjadi salah satu sub materi yang harus diajarkan kepada peserta didik yang beragama Islam. Meskipun tidak bisa dipungkiri, kenyataannya banyak nilai-nilai keislaman yang tidak moderat juga tersampaikan kepada siswa.

Terlepas dari perdebatan dalam penelitian tentang nilai-nilai yang diajarkan, penelitian ini memfokuskan kajian kepada tiga hal. Pertama adalah

${ }^{9}$ Ramayulis, Ilmu Pendidikan Islam (Jakarta: Kalam Mulia, 2010), 56.

${ }^{10}$ H.M. Arifin, "Ilmu Pendidikan Islam," dalam http: //wonk education network. blogspot. com/2007/03/pendidikan-agama-islam.html, diunduh 22 Februari 2021 jam 14.45 WIB. 
mendeskripsikan metode scramble. Kedua adalah menganalisis kondisi pembelajaran PAI selama ini. Ketiga adalah urgensi metode scramble dalam pembelajaran PAI pada sekolah dasar.

\section{Metode}

Dalam penelitian ini, peneliti menggali data dengan wawancara kepada guru-guru PAI yang sudah menerapakan metode scramble dalam pembelajaranya. ${ }^{11}$ Hasil penerapkan metode scramble dan hasil pembelajaranya kemudian dijadikan bentuk dokumen untuk dibaca. Semua hasil dianalisis dan divalidasi menggunakan perpanjangan waktu penelitian. ${ }^{12}$ Sebagai pelengkap rangkaian penelitian, peneliti melakukan observasi secara natural

\section{Temuan dan Pembahasan Temuan penelitian}

Pemahaman dasar guru-guru PAI tentang scramble sebagai suatu perebutan, pertarungan, berusaha mencari jalan keluar untuk menyelesaikan masalah. Dalam konteks pembelajaran, scramble sering dipahami sebagai bentuk pembelajaran menggunakan media huru-huruf untuk menyusun jawaban berdasarkan pertanyaan-pertanyaan yang disampaikan oleh guru. ${ }^{13}$ Meskipun demikian, guru juga harus mempunyai beberapa cara untuk memberikan kunci pemahaman pertanyaan-pertanyaan yang telah diajukan.

Menurut peneliti bidang pendidikan, metode pembalajaran scramble adalah salah satu model pembelajaran kooperatif tipe scramble. ${ }^{14}$ Metode ini merangsang siswa untuk lebih peka dalam menjawab pertanyaan-pertanyaan guru sesuai dengan keahlian dan ketepatan menamukan kunci-kunci jawaban. Dalam pemahaman yang lebih luas, metode scramble sering digunakan untuk para siswa menyelesaikan berbagai permasalahan. ${ }^{15}$ Bagi guru PAI SDN Balonggabus Candi Sidoarjo metode ini bisa digunakan untuk menanamkan nilai-nilai yang ada dalam materimateri PAI. Akan tetapi, guru harus menyiapkan konsep-konsep yang disampaiakn secara kreatif dengan cara menyusun huruf-huruf yang disusun
11Moh. Nazir, Metode Penelitian (Jakarta: Balai Aksara, 2015), 64.

${ }^{12}$ S. Nasution, Metode Penelitian Naturalistik Kualitatif (Bandung: Tarsito, 2012), 2.

13Jhon M. Echols dan Hasan Shadiliy, Kamus Ingrris Indonesia (Jakarta: Gramedia, 2003), 504 .

164
14Trianto, Mendesain Model Pembelajaran Inovatif Progresif (Jakarta: Kencana Media Group, 2011), 9-11.

${ }^{15}$ Aris Shoimin, 68 Model Pembelajaran Inovatif dalam Kurikulum 2013 (Bandung: Ar-Ruzz Media, 2014), 160. 
secara acak sehingga membentuk suatu jawaban atau pasangan konsep. ${ }^{16}$

Metode scramble mengharuskan siswa menemukan konsep materi secara aktif, kreatif, efektif, interaktif dan menyenangkan bagi siswa, sehingga konsep mudah dipahami dan bertahan lama dalam struktur kognitif siswa. Metode ini mengharuskan untuk menggabungkan otak kanan dan otak kiri. Dalam metode ini, peserta didik tidak hanya diminta untuk menjawab soal, tetapi juga menangkap dengan cepat jawaban soal yang sudah tersedia, namun masih dalam kondisi acak. Ketepatan dan kecepatan berpikir dalam menjawab soal menjadi salah satu kunci permainan metode scramble. ${ }^{17}$

Teknik ini membutuhkan media dengan pertanyaan dan jawaban yang ditulis pada sebuah kertas. Pertanyaan yang dibuat disesuaikan dengan bahan ajar yang harus dikuasai peserta didik. Jawaban atas pertanyaan diberikan pada lembar yang sama dengan mengacak hurufnya. ${ }^{18}$ Melalui pembelajaran scramble, siswa dilatih berkreasi

\footnotetext{
16Kokom Komalasari, Pembelajaran Kontekstual Konsep dan Aplikasi (Bandung: Refika Aditama, 2010), 84.

17Miftahul Huda, Model Pengajaran dan Pembelajaran Isu-isu Metodis dan Pragmatis (Yogyakarta: Pustaka Pelajar, 2013), 303-304.

menyusun kata, kalimat atau wacana yang susunannya dengan susunan yang bermakna dan mungkin lebih baik dari susunan aslinya.

Metode scramble ini sesuai untuk semua mata pelajaran. Sesuai dengan sifat jawabannya, scramble terdiri atas bermacam-macam bentuk, yaitu:

a. Scramble kata, yaitu sebuah permainan menyusun kata-kata dan huruf-huruf yang telah dikacaukan letaknya sehingga membentuk suatu kata tertentu yang bermakna, misalnya: $\operatorname{tpeian=petani,~kberjae=}$ bekerja.

b. Scramble kalimat, yaitu sebuah permainan menyusun kalimat dari kata-kata acak. Bentuk kalimat hendaknya logis, bermakna, tepat dan benar. Contoh: pergi - aku - bus - ke - naik - Bandung $=$ aku pergi ke Bandung naik bus.

c. Scramble wacana, yaitu sebuah permainan menyusun wacana logis berdasarkan kalimat-kalimat acak. ${ }^{19}$

Berdasarkan penjelasan di atas dapat ditarik kesimpulan bahwa metode scramble terdiri atas beberapa macam,

18Ridwan Abdullah Sani, Inovasi Pembelajaran (Jakarta: Bumi Aksara, 2013), 248.

${ }^{19}$ Aris Shoimin, 68 Model Pembelajaran Inovatif, 166. 
yaitu scramble kata, scramble kalimat dan scramble wacana. Dari ketiga macam bentuk scramble di atas, sintaks model pembelajaran scramble disajikan pada tabel berikut: ${ }^{20}$

Tabel 1

Sintaks Metode Pembelajaran Scramble

\begin{tabular}{|c|c|c|}
\hline Tahap & $\begin{array}{c}\text { Kegiatan } \\
\text { Guru }\end{array}$ & $\begin{array}{c}\text { Aktivitas } \\
\text { Siswa }\end{array}$ \\
\hline $\begin{array}{l}\text { Fase } 1 \\
\text { Meteri yang } \\
\text { disampaia- } \\
\text { kan adalah } \\
\text { tujuan dan } \\
\text { menyiap- } \\
\text { kan siswa } \\
\text { sesuai } \\
\text { dengan } \\
\text { materi yang } \\
\text { akan } \\
\text { disampai- } \\
\text { kan }\end{array}$ & $\begin{array}{l}\text { Menjelas- } \\
\text { kan tujuan } \\
\text { pembelajar } \\
\text { an dan } \\
\text { memper- } \\
\text { siapkan } \\
\text { siswa } \\
\text { untuk } \\
\text { belajar }\end{array}$ & $\begin{array}{l}\text { Siswa } \\
\text { memahami } \\
\text { penjelasan } \\
\text { guru } \\
\text { tentang } \\
\text { tujuan } \\
\text { pembela- } \\
\text { jaran dan } \\
\text { praktik } \\
\text { pembelajar } \\
\text { an } \\
\text { menggu- } \\
\text { nakan } \\
\text { metode } \\
\text { scramble }\end{array}$ \\
\hline $\begin{array}{l}\text { Fase } 2 \\
\text { Menyampai } \\
\text { kan materi } \\
\text { yang telah } \\
\text { disiapkan }\end{array}$ & $\begin{array}{l}\text { Menyampai } \\
\text { kan tentang } \\
\text { pokok } \\
\text { materi } \\
\text { yang akan } \\
\text { diajarkan } \\
\text { dan } \\
\text { menyiap- } \\
\text { kan kartu }\end{array}$ & $\begin{array}{l}\text { Siswa } \\
\text { mendengar } \\
\text { kan pen- } \\
\text { jelasan } \\
\text { pokok } \\
\text { materi } \\
\text { yang akan } \\
\text { dipelajari } \\
\text { dan mulai }\end{array}$ \\
\hline
\end{tabular}

\begin{tabular}{|c|c|c|}
\hline & $\begin{array}{l}\text { soal dan } \\
\text { jawaban }\end{array}$ & $\begin{array}{l}\text { mencari } \\
\text { informasi } \\
\text { mengenai } \\
\text { materi } \\
\text { pelajaran }\end{array}$ \\
\hline $\begin{array}{l}\text { Fase } 3 \\
\text { Memeben- } \\
\text { tuk siswa- } \\
\text { siswa } \\
\text { dalam } \\
\text { beberapa } \\
\text { kelompok }\end{array}$ & $\begin{array}{l}\text { Memberi } \\
\text { intruksi } \\
\text { kepada } \\
\text { siswa } \\
\text { untuk } \\
\text { membuat } \\
\text { kelompok } \\
\text { belajar dan } \\
\text { membagi } \\
\text { kartu soal } \\
\text { dan } \\
\text { jawaban } \\
\text { yang diacak } \\
\text { susunanny } \\
\text { a }\end{array}$ & $\begin{array}{l}\text { Siswa } \\
\text { memben- } \\
\text { tuk } \\
\text { kelompok } \\
\text { tujuh } \\
\text { kelompok } \\
\text { sesuai } \\
\text { intruksi } \\
\text { yang } \\
\text { diberikan } \\
\text { oleh guru }\end{array}$ \\
\hline $\begin{array}{l}\text { Fase } 4 \\
\text { Membim- } \\
\text { bing } \\
\text { pelatihan }\end{array}$ & $\begin{array}{l}\text { Membantu } \\
\text { kelompok } \\
\text { belajar } \\
\text { selama } \\
\text { siswa } \\
\text { mengerja- } \\
\text { kan } \\
\text { tugasnya } \\
\text { dan } \\
\text { memba- } \\
\text { gikan kartu } \\
\text { jawaban }\end{array}$ & $\begin{array}{l}\text { Siswa } \\
\text { menanyaka } \\
\text { n hal-hal } \\
\text { yang } \\
\text { kurang } \\
\text { dipahami, } \\
\text { siswa } \\
\text { mencocok- } \\
\text { kan kartu } \\
\text { soal dan } \\
\text { kartu } \\
\text { jawaban } \\
\text { berdasar- }\end{array}$ \\
\hline
\end{tabular}

${ }^{20}$ Andika Sofyan, "Penerapan Metode Scramble," 15-19. 
Oleh: Femiliana Haķim

\begin{tabular}{|c|c|c|}
\hline & $\begin{array}{l}\text { dan kartu } \\
\text { soal }\end{array}$ & $\begin{array}{l}\text { kan } \\
\text { jawaban } \\
\text { yang } \\
\text { telah } \\
\text { mereka } \\
\text { diskusikan } \\
\text { sebelum- } \\
\text { nya. } \\
\text { Siswa } \\
\text { menyusun } \\
\text { proses } \\
\text { Menemu- } \\
\text { kan } \\
\text { jawaban } \\
\text { yang } \\
\text { tepat pada } \\
\text { kartu soal }\end{array}$ \\
\hline $\begin{array}{l}\text { Fase } 5 \\
\text { Penelian } \\
\text { secara } \\
\text { menye- } \\
\text { luruh }\end{array}$ & $\begin{array}{l}\text { Menguji } \\
\text { pengeta- } \\
\text { huan siswa } \\
\text { mengenai } \\
\text { materi } \\
\text { pelajaran } \\
\text { sesuai } \\
\text { dengan } \\
\text { tujuan } \\
\text { pembelajar } \\
\text { an dengan } \\
\text { memberi- } \\
\text { kan perta- } \\
\text { nyaan } \\
\text { kepada } \\
\text { setiap } \\
\text { kelompok }\end{array}$ & $\begin{array}{l}\text { Setiap } \\
\text { kelompok } \\
\text { berdiskusi } \\
\text { untuk } \\
\text { menjawab } \\
\text { pertanyaan }\end{array}$ \\
\hline
\end{tabular}

\begin{tabular}{|c|c|c|}
\hline $\begin{array}{l}\text { Fase } 6 \\
\text { Membe- } \\
\text { rikan } \\
\text { penghar- } \\
\text { gaan }\end{array}$ & $\begin{array}{l}\text { Memper- } \\
\text { siapkan } \\
\text { penghar- } \\
\text { gaan } \\
\text { kepada } \\
\text { kelompok } \\
\text { yang men- } \\
\text { cocokkan } \\
\text { kartu soal } \\
\text { dan ja- } \\
\text { waban } \\
\text { secara } \\
\text { cepat dan } \\
\text { benar }\end{array}$ & $\begin{array}{l}\text { Kelompok } \\
\text { yang } \\
\text { mencocok- } \\
\text { kan kartu } \\
\text { soal dan } \\
\text { jawaban } \\
\text { secara } \\
\text { cepat dan } \\
\text { benar akan } \\
\text { mendapat } \\
\text { pengharga } \\
\text { an }\end{array}$ \\
\hline
\end{tabular}

melakukan proses pembelajaran dengan menggunakan metode scramble, agar lebih sistematis, maka diperlukannya langkah-langkah pembelajaran seperti yang dikemukakan oleh Miftahul Huda adalah sebagai berikut:

a. Guru menyampaikan materi sesuai perencanaan pembelajaran

b. Guru membuat kelompok

c. Guru membagikan lembar kerja yang sudah disiapkan

d. Guru menetapakan durasi waktu dalam menyelesaikan semua soal

e. Guru mengawasi proses penyelesaiakan soal-soal yang telah diberikan

f. Jika waktu mengerjakan soal sudah habis, siswa wajib mengumpulkan lembar jawaban kepada guru. Dalam 
hal ini, baik siswa yang selesai maupun tidak selesai, harus mengumpulkan jawaban itu

g. Guru melakukan penilaian,

h. Guru mengumumkan hasil penilaian. $^{21}$

Di samping itu, hasil pengarahan supervise pendidikan SDN Balonggabus Candi Sidoarjo memberikan aturan langkah-langkah pembelajaran scramble menjadi tiga tahap, yaitu persiapan, inti dan tindak lanjut. Penjelasan dari ketiganya adalah sebagai berikut:

a. Persiapan. Pada tahap ini guru menyiapkan bahan dan media yang akan digunakan dalam pembelajaran. Media yang digunakan berupa kartu soal dan kartu jawaban yang telah diacak sedemikian rupa. Guru menyiapkan kartu-kartu sebanyak kelompok yang telah dibagi. Guru mengatur hal-hal yang mendukung proses belajar mengajar, misalnya mengatur tempat duduk sesuai kelompok yang telah dibagi ataupun memeriksa kesiapan siswa belajar dan lain sebagainya.

b. Kegiatan inti. Kegiatan dalam tahap ini adalah setiap kelompok melakukan diskusi untuk mengerjakan soal dan mencari kartu soal untuk jawaban yang cocok. Sebelumnya jawaban telah diacak sedemikian rupa.

c. Tindak lanjut. Kegiatan tindak lanjut tergantung dari hasil belajar peserta $\operatorname{didik.~}^{22}$

Berdasarkan langkah-langkah metode scramble di atas, dapat ditarik kesimpulan bahwa metode scramble bersifat aktif, siswa dituntut aktif bekerja sama serta bertanggung jawab terhadap kelompoknya untuk menyelesaikan kartu soal guna memperoleh poin dan diharapkan dapat meningkatkan kebersamaan siswa. Dengan metode ini diharapkan hasil pembelajaran akan lebih bermakna bagi siswa dan pada akhirnya siswa dapat menemukan banyak hal yang menarik dalam pembelajaran dan hasil kelompok mereka, sehingga siswa dapat menemukan suatu ilmu atau pengetahuan dengan lebih bermakna.

Semua metode pembelajaran tidak ada yang sempurna, pasti memiliki kelebihan dan kekurangan. Begitu juga dengan scramble. Adapun kelebihan metode scramble antara lain, (1) memudahkan peserta didik untuk

\footnotetext{
21Miftahul Huda, Model Pengajaran dan ${ }^{22}$ Aris Shoimin, 68 Model Pembelajaran Inovatif, Pembelajaran, 304-305. 168 166. 
menemukan jawaban, (2) mendorong peserta didik untuk mengerjakan soal tersebut karena jawaban sudah tersedia, (3) semua peserta didik terlibat. Kegiatan pembelajaran dengan scramble tersebut dapat mendorong pemahaman peserta didik terhadap materi semua mata pelajaran. Metode ini cukup efektif dalam meningkatkan motivasi dan minat peserta didik sehingga hasil belajar dan prestasi belajarnya lebih baik. $^{23}$ Setiap anggota kelompok bertanggung jawab atas segala sesuatu yang dikerjakan dalam kelompoknya. Maka dari itu, dalam teknik ini setiap siswa tidak ada yang diam karena setiap individu diberi tanggung jawab akan keberhasilan kelompoknya.

Sedangkan kekurangan pada model pembelajaran scramble adalah:

a. Pada pembelajaran ini terkadang sulit dalam merencanakannya karena terbentur dengan kebiasaan siswa belajar.

b. Terkadang dalam mengimplementasikannya, memerlukan waktu yang panjang, sehingga guru sulit menyesuaikan dengan waktu yang telah ditentukan. c. Selama kriteria keberhasilan belajar ditentukan oleh kemampuan peserta didik menguasai materi pelajaran, pembelajaran ini akan sulit diimplementasikan guru.

d. Siswa bisa saja mencontek jawaban temannya.

e. Siswa tidak dilatih untuk berpikir kreatif.

f. Siswa menerima bahan mentah yang hanya perlu diolah dengan baik. ${ }^{24}$

\section{Pembelajaran PAI}

Pendidikan Agama Islam (PAI) adalah salah satu sub sistem dari pendidikan Islam. PAI sendiri sering didefinisikan sebagai suatu usaha untuk membina dan mengasuh peserta didik agar senantiasa dapat memahami ajaran Islam secara menyeluruh. Lalu menghayati tujuan yang pada akhirnya dapat mengamalkan serta menjadikan Islam sebagai pandangan hidup. ${ }^{25}$

Pendidikan agama merupakan pendidikan yang memperbaiki sikap dan tingkah laku manusia. Membina budi pekerti luhur seperti kebenaran, keikhlasan, kejujuran, keadilan, kasih sayang, cinta mencintai, dan menghidupkan hati nurani manusia untuk memperhatikan (muraqabah) kepada

25Zakiah Darajat, Ilmu Pendidikan Islam (Jakarta: Bumi Aksara, 2008), 1.
${ }^{23}$ Nurlina, "Penerapan Metode Scramble," 267. ${ }^{24}$ Miftahul Huda, Model-Model Pengajaran dan Pembelajaran, 306. 
Allah SWT, baik dalam keadaan sendirian maupun bersama orang lain. Agama merupakan sarana yang menjamin kelapangan dada. ${ }^{26}$

Definisi pendidikan agama Islam disebutkan dalam kurikulum 2004 Standar Kompetensi Mata Pelajaran Pendidikan Agama Islam SD yaitu upaya sadar dan terencara dalam menyiapkan peserta didik untuk mengenal, memahami, menghayati, mengimani, bertakwa, berakhlak mulia, mengamalkan ajaran agama Islam dari sumber utamanya kitab suci al-Qur'an dan hadits, melalui kegiatan bimbingan, pengajaran, latihan serta penggunaan pengalaman. ${ }^{27}$

Berdasarkan dari beberapa pengertian pendidikan agama Islam tersebut, dapat disimpulkan bahwa pendidikan agama Islam berarti usaha secara sistematis dan pragmatis Islam melalui pembinaan, pembimbingan dan pelatihan untuk mengubah tingkah laku individu secara keseluruhan, membantunya agar bisa hidup sesuai dengan ajaran Islam, dan usaha untuk menumbuhkan manusia muslim sempurna, melalui berbagai macam latihan dalam berbagai aspeknya yang bersumber dari kitab suci al-Qur'an dan hadits.

Pendidikan tidak hanya dipandang sebagai usaha pemberian informasi dan pembentukan keterampilan saja, namun diperluas. Sehingga mencakup usaha keinginan, kebutuhan dan kemampuan individu untuk mencapai pola hidup pribadi dan sosial yang memuaskan. Oleh karena itu, untuk kehidupan anak sekarang yang sedang mengalami perkembangan menuju ke tingkat kedewasaannya bisa memahami dasardasar dari pendidikan agama Islam untuk selanjutnya. ${ }^{28}$

Ramayulis menyatakan mengikuti sistematika iman, Islam dan ihsan yang berasal dari Nabi Muhammad SAW, dapat dikemukakan bahwa dasar agama Islam terdiri dari akidah, syariah dan akhlak. ${ }^{29}$ Akidah, menurut etimologi, adalah ikatan pada iman. Menurut terminologi, akidah adalah keyakinan yang ditautkan dengan rukun iman, dimana rukun iman merupakan asas seluruh ajaran Islam.

5/02/ tujuan- pendidikan-agama-islam/, diunduh 27 Mei 2021 pukul 17.03 WIB.

${ }^{28}$ Ihsan Fuad, Dasar-Dasar Kependidikan (Jakarta: Rineka Cipta, 2010), 5.

${ }^{29}$ Ramayulis, Ilmu Pendidikan Islam, 133. 
Syariah sebagai nilai-nilai luhur agama yang sifatnya mutlak itu sangat penting diperlukan dalam kehidupan dan berguna bagi umat manusia dalam upaya memperoleh ridha Allah Swt sebagai perwujudan perintah dan larangan-Nya. ${ }^{30}$ Akhlak adalah nilai-nilai dan sifat-sifat yang tertanam dalam jiwa, yang dengan sorotan dan timbangannya seseorang dapat menilai perbuatannya baik atau buruk. Betapa pentingnya akhlak dalam kehidupan manusia dalam pandangan Islam, niscaya dijadikan dasar dan tujuan dalam pendidikan agama Islam. ${ }^{31}$

Dengan demikian membawa pengertian bahwa bagaimanapun sederhananya suatu komunitas manusia, dia memerlukan adanya pendidikan. Fungsi pendidikan agama Islam sebagaimana dijelaskan dalam kurikulum yaitu sebagai berikut:

a. Pengembangan, yaitu meningkatkan keimanan ketakwaan peserta didik kepada Allah Swt yang telah ditanamkan dalam lingkungan keluarga.

b. Penanaman nilai sebagai pedoman hidup untuk mencari kebahagiaan hidup di dunia dan di akhirat. c. Penyesuaian mental, yaitu untuk

30Ihsan Fuad, Dasar-Dasar Kependidikan, 161. 31Ilyas Yunahar, Kuliah Akhlak (Yogyakarta: LPPIUMG, 2006), 2. el Bidayah: Journal of Islamic Elementary Education Volume 3, Nomor 2, September 2021 menyesuaikan diri dengan lingkungannya, baik lingkungan fisik maupun lingkungan sosial dan dapat mengubah lingkungannya sesuai dengan ajaran Islam.

d. Perbaikan, yaitu untuk memperbaiki kesalahan-kesalahan, kekurangankekurangan dan kelemahan-kelemahan peserta didik dalam keyakinan, pemahaman dan pengalaman ajaran dalam kehidupan sehari-hari.

e. Pencegahan, yaitu untuk menangkal hal-hal negatif dari lingkungannya atau dari budaya lain yang dapat membahayakan dirinya dan menghambat perkembangannya menuju manusia Indonesia seutuhnya.

f. Pengajaran, yaitu tentang ilmu pengetahuan keagamaan secara umum (alam nyata dan nir-nyata), sistem dan fungsionalnya.

g. Penyaluran, yaitu untuk menyalurkan anak-anak yang memiliki bakat khusus di bidang agama Islam agar bakat tersebut dapat berkembang secara optimal sehingga dapat dimanfaatkan untuk dirinya sendiri dan bagi orang lain. ${ }^{32}$

Materi pendidikan agama Islam pada sekolah atau madrasah dasar

${ }^{32}$ Abdul Majid dan Dian Andayani. Pendidikan Agama Islam Berbasis Kompetensi (Bandung: PT Remaja Rosdakarya, 2004), 134. 
merupakan integral dari program pengajaran setiap jenjang pendidikan. Sesuai dengan tujuan pendidikan nasional, pendidikan agama Islam diarahkan untuk membentuk manusia Indonesia seutuhnya. Adapun materi pokok Pendidikan Agama Islam dapat diklasifikasikan menjadi lima aspek kajian, yaitu:

a. Aspek al-Qur'an dan Hadits. Dalam aspek ini menjelaskan beberapa ayat dalam al-Qur'an dan sekaligus juga menjelaskan beberapa hukum bacaannya yang terkait dengan ilmu tajwid dan juga menjelaskan beberapa hadits Nabi Muhammad SAW.

b. Aspek keimanan (aqidah) Islam. Dalam aspek ini menjelaskan berbagai konsep keimanan yang meliputi enam rukun iman dalam Islam.

c. Aspek akhlak. Dalam aspek ini menjelaskan berbagai sifat-sifat terpuji (akhlaq al-karimah) yang harus diikuti dan sifat-sifat tercela (akhlaq al-madzmumah) yang harus dijauhi.

d. Aspek hukum Islam (syari'ah). Dalam aspek ini menjelaskan berbagai konsep keagamaan yang terkait dengan masalah ibadah dan mu'amalah.

e. Aspek tarikh Islam. Dalam aspek ini menjelaskan sejarah perkembangan atau peradaban Islam yang bisa diambil manfaatnya untuk diterapkan di masa sekarang. 33

Metode pembelajaran PAI yang digunakan selama ini memiliki kedudukan yang amat strategis dalam mendukung keberhasilan pengajaran. Itulah sebabnya, para ahli pendidikan sepakat, bahwa seseorang guru yang ditugaskan mengajar di sekolah, harus guru yang profesional, yaitu guru yang antara lain ditandai oleh penguasaan yang prima terhadap metode pengajaran. Melalui metode pengajaran, mata pelajaran dapat disampaikan secara efesien, efektif dan terukur dengan baik, sehingga dapat dilakukan perencanaan dan perkiraan dengan tepat.

Secara umum, dilihat dari segi langkah-langkah dan tujuan kompetensi yang ingin dicapai dalam pendidikan atau pembelajaran, terdapat sejumlah metode yang digunakan dalam pembelajaran PAI di jenjang sekolah dasar. Di antaranya adalah metode

${ }^{33}$ Ditjen Dikdasmen Depdiknas, Pedoman Khusus Pengembangan Silabus Berbasis Kompetensi SekolahMenengah Pertama (Jakarta: Depdiknas, 172 2004), 18. 
ceramah, metode tanya jawab, metode demonstrasi, metode karya wisata, metode sosiodrama, metode pemberian tugas, metode hapalan dan metode praktek. Berdasarkan kondisi riil tersebut, diperlukan sebuah metode pembelajaran alternatif seperti scramble dalam pembelajaran PAI agar proses pembelajaran tidak menjadi monoton.

\section{Urgensi Metode Scramble dalam Pembelajaran PAI}

PAI dimaknai sebagai upaya sadar dan terencana dalam menyiapkan peserta didik untuk mengenal, memahami, menghayati, hingga mengimani, bertakwa dan berakhlak mulia dalam mengamalkan ajaran agama Islam dari sumber utamanya kitab suci al-Qur'an dan hadits, melalui kegiatan bimbingan, pengajaran, latihan serta penggunaan pengalaman. Dengan penggunaan metode Scramble, guru dapat meningkatkan daya pemikiran siswa. Metode ini bisa mendorong siswa untuk berpikir secara aktif dengan materi (kata acak) yang ada.

Siswa dianjurkan untuk menjawab pertanyaan yang kata-katanya diacak.
Permainan ini sangat baik untuk mengambangkan daya pikir tinggi siswa. Dengan cara seperti ini pembelajaran yang berupa fakta-fakta sejarah Islam yang berusia tua di dalam PAI terasa lebih segar dan dekat dengan siswak.

Scramble merupakan pembelajaran dengan menerapkan bentuk permainan yang dapat memancing kemampuan membaca surat-surat pendek pilihan siswa yang ada di dalam al-Qur'an. Dengan strategi pembelajaran ini, diharapkan dapat meningkatkan kemampuan membaca al-Quran, khususnya pada mata pelajaran PAI, dapat meningkat. ${ }^{34}$

Tujuan metode scramble dalam proses pembelajaran PAI bertujuan untuk mempermudahkan para siswa untuk menghafal kata-kata yang sulit atau catatan yang penting. Seperti mengingat nama tokoh-tokoh atau tempat-tempat bersejarah. Scramble merupakan salah satu dari permainan bahasa yang bertujuan untuk membangkitkan kembali kesegaran belajar siswa yang mulai lesu.

Kelas V SDN 018 Tandan Sari Kecamatan Tapung Hilir Kabupaten Kampar," Skripsi (Pekanbaru: UIN Syarif kasim, 2010), 10-13.
${ }^{34}$ Nurwidar, “"Penerapan Strategi Pembelajaran Scramble Untuk Meningkatkan Kemampuan Membaca Al-Qur'an Surat Pendek Pilihan Pada Mata Pelajaran Pendidikan Agama Islam Siswa el Bidayah: Journal of Islamic Elementary Education Volume 3, Nomor 2, September 2021 
Sikap kompetitif yang ada dalam permainan, dapat mendorong siswa berlomba-lomba maju yang tidak kalah menarik dari permainan ini adalah materi yang komunikasikan lewat permainan bahasa biasanya berkesan sehingga sukar dilupakan. Permainan scramble bertujuan untuk mengembangkan daya pikir tinggi peserta didik dengan materi (kata acak) yang ada. ${ }^{35}$

Adapun langkah-langkah dalam metode scramble yang harus dipersiapkan oleh guru mata pelajaran PAI pada jenjang sekolah dasar, yaitu:

1. Guru menjelaskan materi yang berhubungan dengan soal dan jawaban yang akan diberikan. Sebelumnya guru telah menyiapkan kartu soal dan jawaban tersebut.

2. Guru harus memahami betul apa saja istilah atau kata yang dianggap sulit bagi siswa dalam sebuah mata pelajaran. Kata-kata itulah yang nant-inya memerlukan penguatan yang diwujudkan dalam bentuk soal.

3. Untuk membangun kekompakan dan kebersamaan, siswa dibagi menjadi kelompok-kelompok kecil.
4. Selama proses pembelajaran berjalan, guru dapat memberikan clue tambahan jika siswa mengalami kesulitan dalam berpikir.

5. Guru memberikan pemahaman kepada siswa tentang metode pembelajaran yang akan diterapkan serta membagikan kartu soal dan kartu jawaban.

6. Guru memberi durasi tertentu untuk pengerjaan soal.

7. Guru mengecek durasi waktu sambil memeriksa pekerjaan masingmasing kelompok dan memberikan clue tambahan jika siswa mengalami kesulitan dalam berpikir.

8. Jika waktu pengerjaan soal sudah habis, siswa wajib mengumpulkan lembar jawaban. Dalam hal ini, baik siswa yang selesai maupun tidak selesai harus mengumpulkan jawabannya segera.

9. Guru melakukan penilaian, baik di kelas maupun di rumah. Penilaian dilakukan berdasarkan seberapa cepat siswa mengerjakan soal dan seberapa banyak soal yang dapat diselesaikan dengan benar.

10. Guru dapat memberi apresiasi kepada siswa yang berhasil dan

${ }^{35}$ Yenni Octavia, "Pengaruh Metode Scramble," 286-297. 
memberikan semangat kepada yang belum berhasil menjawab dengan cepat dan benar. ${ }^{36}$

\section{Pembahasan}

Pembelajaran mata pelajaran PAI pada jenjang sekolah dasar selama ini diidentikkan dengan metode ceramah. Sebagai metode yang paling murah dan paling mudah dilaksanakan bagi para guru, ceramah menjadikan siswa mudah bosen. Kondisi ini membawa dampak perhatian siswa kepada pembelajaran kurang fokus.

Fakta ini mendorong para guru PAI untuk makin kreatif dan aktif dalam mencari metode pembelajaran yang semakin merangsang siswa tertarik dengan mata pelajarannya. Dibutuhkan upaya yang tidak sedikit tenaga dan pikiran untuk memperolehnya. Namun hal itu harus dilaksanakan agar tujuan pembelajaran yang sudah disusun mampu dicapai secara optimal.

Metode scramble, meski masih tergolong baru, namun lambat laun makin banyak digunakan para guru PAI di jenjang sekolah dasar. Hal ini didasarkan karena pelaksanaan metode scramble tidak membutuhkan tenaga dan pikiran yang tinggi, sebagaimana penggunaan metode ceramah. Pada metode ceramah, yang terjadi adalah guru sebagai satu-satunya sumber belajar (teache center).

Penggunaan metode scramble dalam pembelajaran PAI mendorong adanya perubahan paradigma. Pembelajaran yang dilaksanakan guru bersama siswanya akan berorientasi kepada aktivitas siswa. Hal ini berarti bahwa student center benar-benar terwujud dengan penggunaan metode scramble.

Terdapat empat hal mendasar dalam sebuah pembelajaran PAI agar makin bermakna bagi siswa dengan metode scramble. Pertama adalah mengidentifikasi serta menetapkan spesifikasi dan kualifikasi perubahan tingkah laku dan keperibadian siswa sebagaimana yang diharapkan. Kedua adalah memilih sistem pendekatan belajar mengajar berdasarkan aspirasi dan pandangan hidup masyarakat. Ketiga adalah memilih dan menetapkan prosedur, metode dan teknik belajar mengajar yang dianggap paling tepat dan efektif sehingga dapat dijadikan pegangan oleh guru dalam menunaikan kegiatan mengajarnya. Keempat adalah menetapkan norma-norma dan batas

${ }^{36}$ Nurul Syafika, "Pengaruh Penerapan Metode Pembelajaran Scramble," 9-14. 
minimal keberhasilan atau kriteria serta standar keberhasilan sehingga dapat dijadikan pedoman oleh guru dalam melakukan evaluasi hasil kegiatan belajar mengajar yang selanjutnya akan dijadikan umpan balik buat penyempurnaan sistem intruksional yang bersangkutan secara keseluruhan.

Pada penggunaan metode scramble dalam pembelajaran PAI, semua siswa akan terlibat aktif selama pembelajaran. Metode ini juga mendorong para siswa untuk mengerjakan soal tersebut karena jawaban sudah tersedia. Kegiatan pembelajaran dengan scramble tersebut dapat mendorong pemahaman siswa terhadap materi mata pelajaran PAI. Setiap anggota kelompok bertanggung jawab atas segala sesuatu yang dikerjakan dalam kelompoknya. Metode ini cukup efektif dalam meningkatkan motivasi dan minat para siswa sehingga hasil belajar dan prestasi belajarnya lebih baik.

\section{Kesimpulan}

Berdasarkan paparan hasil penelitian dan pembahasan di atas, maka yang menjadi kesimpulan dari tulisan ini adalah sebagai berikut:

1. Metode scramble adalah teknik pembelajaran yang tergolong baru dan mampu menjadikan siswa aktif 176 dalam proses pembelajaran. Metode ini sesuai untuk semua mata pelajaran, terlebih PAI yang membutuhkan pengamalan siswa dalam kehidupan sehari-hari.

2. Kondisi pembelajaran PAI selama ini masih didominasi oleh metode ceramah yang menyebabkan siswa kurang aktif, sehingga mudah jenuh. Fakta ini menyebabkan hasil belajar siswa masih tergolong rendah.

3. Metode scramble semakin penting (urgent) untuk diterapkan dalam pembelajaran PAI pada sekolah dasar. Hal ini didorong keinginan untuk menaikkan hasil belajar siswa dan mengakhiri metode pembelajaran yang selama ini masih monoton.

\section{Daftar Pustaka}

Ahmad, Muhammad Abdul Qadir. Metodologi Pengajaran Agama Islam. Jakarta: Rineka Cipta, 2008.

Ali, Idrus dan Fachrudin Saudagar. Pengembangan

Profesionalitas Guru. Jakarta: GP Pres, 2009.

Arikunto, Suharsimi. Prosedur Penelitian. Jakarta: Rineka Cipta, 2010.

Darajat, Zakiah. Ilmu Pendidikan Islam. Jakarta: Bumi Aksara, 2008.

Ditjen Dikdasmen Depdiknas. Pedoman Khusus Pengembangan Silabus Berbasis Kompetensi 
SekolahMenengah Pertama. Jakarta: Depdiknas, 2004.

Echols, Jhon M. dan Hasan Shadiliy, Kamus Ingrris Indonesia. Jakarta: Gramedia, 2003.

Fitriana, Isna. "Penerapan Model Pembelajaran Scramble Untuk Meningkatkan Hasil Belajar Siswa Pada Materi Tata Nama Senyawa Di SMAN 1 Bireuen." Skripsi. Lampung: IAIN Randen Intan Lampung, 2016.

Fuad, Ihsan. Dasar-Dasar Kependidikan. Jakarta: Rineka Cipta, 2010.

Handini, Gian. "Penerapan Model Pembelajaran Scramble Untuk Meningkatkan Hasil Belajar IPS Siswa Kelas V SDN 21 Palembang." Skripsi. Palembang: Universitas Sriwijaya, 2016.

H.M. Arifin. "Ilmu Pendidikan Islam," dalam http: //wonk education network. blogspot. com/2007/03/pendidikanagama-islam.html, diunduh 22 Februari 2021 jam 14.45 WIB.

Huda, Miftahul. Model Pengajaran dan Pembelajaran Isu-isu Metodis dan Pragmatis. Yogyakarta: Pustaka Pelajar, 2013.

Komalasari, Kokom. Pembelajaran Kontekstual Konsep dan Aplikasi. Bandung: Refika Aditama, 2010.

Majid, Abdul dan Dian Andayani. Pendidikan Agama Islam Berbasis Kompetensi.
Bandung: PT Remaja Rosdakarya, 2004.

Nasution, S. Metode Penelitian Naturalistik Kualitatif. Bandung: Tarsito, 2012.

Nazir, Moh. Metode Penelitian. Jakarta: Balai Aksara, 2015.

Nurlina. "Penerapan Metode Scramble Untuk Meningkatkan Motivasi Belajar Fisika Siswa Kelas X SMA Muhammadiyah Unismuh Makassar." Skripsi. Makassar: Universitas Muhammadiyah, 2018.

Nurwidar. "“Penerapan Strategi Pembelajaran Scramble Untuk Meningkatkan Kemampuan Membaca AlQur'an Surat Pendek Pilihan Pada Mata Pelajaran Pendidikan Agama Islam Siswa Kelas V SDN 018 Tandan Sari Kecamatan Tapung Hilir Kabupaten Kampar." Skripsi. Pekanbaru: UIN Syarif kasim, 2010.

Octavia, Yenni. "Pengaruh Metode Scramble Terhadap Hasil Belajar Siswa Pada Mata Pelajaran Pendidikan Agama Islam SDN 007 Tembilahan Hilir Kecamatan Tembilahan Kabupaten Indragiri Hilir." Jurnal Pendidikan Asatiza, Vol. 1 No. 2 (Mei 2020).

Ramayulis. Ilmu Pendidikan Islam. Jakarta: Kalam Mulia, 2010.

Sani, Ridwan Abdullah. Inovasi Pembelajaran. Jakarta: Bumi Aksara, 2013. 
Sardiman. Interaksi dan Motivasi Belajar

Mengajar. Jakarta: PT

Grafindo Persada, 2012.

Shoimin, Aris. 68 Model Pembelajaran Inovatif dalam Kurikulum 2013. Bandung: Ar-Ruzz Media, 2014.

Sofyan, Andika. "Penerapan Metode Scramble Untuk Meningkatkan Hasil Belajar Fiqih Siswa Kelas VIII E MTS Negeri 1 Lampung Timur Tahun Pelajaran 2018/2019." Skripsi. Lampung Timur: IAIN Metro, 2019.

Syafika, Nurul. "Pengaruh Penerapan Metode Pembelajaran Scramble Terhadap Hasil Belajar Peserta Didik Pada Bidang Studi Pendidikan Agama Islam Kelas VIII di SMPN 5 Maiwa Kabupaten Enrekang." Skripsi. Makasar: UIN Alauddin, 2017.

Trianto. Mendesain Model Pembelajaran Inovatif Progresif. Jakarta: Kencana Media Group, 2011.

Yunahar, Ilyas. Kuliah Akhlak. Yogyakarta: LPPIUMG, 2006. 